\title{
USUL FIKIH: REKONSTRUKSI METODOLOGIS DALAM DINAMIKA HUKUM ISLAM
}

\author{
Efrinaldi \\ Fakultas Syariah UIN Imam Bonjol Padang \\ J. Jalan M. Yunus Lubuk Lintah Padang \\ Email: efrinaldi_74@yahoo.co.id
}

\begin{abstract}
The philosophical-historical analysis on Islamic law amid the society is becoming an increasing focus of attention, especially for academicians. Their debates, to some extend, are nearly touching even the sacralized matter. But it is also regrettable that what they have discussed so far are merely the problems on the surface and considered trivial as they do not touch the core of the problem likes establishing a new-accepted and relevant theory. What they have done or discussed are merely repetitive. The point to be discussed here is the sacralization of the thoughts and blind following toward one thought of school. Employing the philosophical-historical analysis on Islamic law and it relationship with the Islamic jurisprudence and comparing it with the contemporary methodology, this writing is aimed at looking for new formula on the Islamic jurisprudence reasoning with the development of methodology of Islamic studies.
\end{abstract}

Keywords: Islamic jurisprudence methodology, dynamism, Islamic law

\begin{abstract}
Abstrak: Analisis filosofis-historis pada hukum Islam di tengah masyarakat menjadi fokus perhatian yang semakin meningkat, terutama bagi para akademisi. Perdebatan mereka, sampai batas tertentu, hampir menyentuh bahkan materi yang disakralkan. Tetapi disesalkan juga bahwa apa yang telah mereka diskusikan sejauh ini hanyalah masalah di permukaan dan dianggap sepele, karena mereka tidak menyentuh inti masalah seperti membangun teori yang baru diterima dan relevan. Apa yang telah mereka lakukan atau diskusikan hanyalah berulang. Poin yang akan dibahas di sini adalah sakralisasi pikiran dan ketertarikan buta terhadap satu pemikiran sekolah. Mempekerjakan analisis filosofis-historis pada hukum Islam dan hubungannya dengan yurisprudensi Islam lalu membandingkannya dengan metodologi kontemporer, tulisan ini ditujukan untuk mencari formula baru pada penalaran yurisprudensi Islam dengan pengembangan metodologi studi Islam.
\end{abstract}

Kata kunci: Usul Fikih, dinamika, hukum Islam

\section{Pendahuluan}

Rekonstruksi penalaran dalam usul fikih tampak signifikan sebagai metode dalam menggali dan menetapkan hukum Islam. Dalam konteks ini, ilmu usul fikih sangat urgen bagi para mujtahid dalam meng-istinbath-kan hukum syara' secara benar dan solutif terhadap problematika yang berkaitan dengan hukum Islam.

Eksistensi hukum Islam pada dasarnya bersifat konstan; tidak terpengaruh oleh ruang dan waktu. Interpretasi umat Islam yang selalu berubah, sesuai dengan perubahan kondisi sosiohistoris, mobilitas sosial, dan kemajuan zaman. Hukum Islam menerima interpretasi, sejauh tidak bertentangan dengan maksud dan tujuan syara'. Interpretasi ini yang kemudian menjadi fikih imam mazhab dalam Islam. Atas dasar ini, hukum Islam tersebut mencakup syara' dan juga hukum fikih, karena arti syara' dan fikih terkandung di dalamnya. ${ }^{1}$

Karakteristik hukum Islam sangat elastis dalam dinamika perubahan sosial. Hukum Islam tumbuh dalam berbagai situasi dan kondisi yang mengitari

\footnotetext{
${ }^{1}$ Amir Syarifuddin, Pembaharuan Pemikiran dalam Hukum Islam, (Padang: Angkasa Raya, 1990), h. 18.
} 
umat Islam. ${ }^{2}$ Realitas ontologis hukum Islam kemudian melahirkan epistemologi fikih yang pada dasarnya merupakan resultante dan interaksi para ulama dengan fakta sosial yang melingkupinya. ${ }^{3}$ Fakta sejarah tersebut menunjukan bahwa fikih menjustifikasi pluralitas formulasi epistemologi hukum disebabkan adanya peran language games yang berbeda.

Di sisi lain, transformasi hukum Islam kemudian banyak mengalami dinamika dan perkembangan selama 14 abad sejak diturunkan ke dunia. Karena hukum Islam bertujuan untuk mengatur kepentingan manusia dalam mencapai kemaslahatan hidupnya, maka ia senantiasa berkembang dan berjalan sesuai dengan situasi, kondisi, dan gerak laju perkembangan umat Islam. Dinamika perkembangan tersebut adakalanya berupa kemajuan, tapi pada waktu tertentu hukum Islam mengalami stagnasi dan degradasi, sehingga terlantar di tangan umat Islam sendiri.

Fleksibelitas struktur fundamental hukum Islam secara praksis kadangkala tidak diimbangi dengan produktifitas pemahaman substantif melalui metode ijtihad. Implikasinya, tradisi ilmu-ilmu keislaman, khususnya ilmu fikih dan ushul, terutama pasca abad $10 \mathrm{M}$ cenderung legal-formalistik dan stagnan. Asumsi bahwa fikih yang ada telah memuat pokok-pokok hukum Ilahi (syariah), telah menghambat interpretasi substantif ijtihad tersebut, lalu tradisi taqlid menjadi tumbuh subur. ${ }^{4}$ Situasi ini menjadi semakin parah ketika teks-teks interpretatif hukum Islam dijadikan teks otoritatif. Padahal tidak jarang, teks tersebut hanya merupakan komentar (syarh) atau bahkan mungkin komentar atas komentar (hasyiyah) sehingga teks pertama justru menjadi hilang. Pada gilirannya, rumusan hukum Islam kehilangan relevansinya dengan realitas kehidupan praktis.

\footnotetext{
2 Seyyed Hossein Nasr, A Young Muslim's Guide to the Modern World, terj. Hasti Tarekat (Bandung: Mizan, 1993), h. 56.

3 Ahmad Hasan, The Early Development of Islamic Jusriprudence, (Islamabad: Islamic Research Institute, 1988), h. 24-25.

${ }^{4}$ John L. Esposito, The Islamic Threat: Myth or Reality?, terj. Alwiyah Abdurrahman, (Bandung: Mizan, 1994), h.46.
}

\section{Mashadir al-Ahkam: \\ Sumber Metodologi Yurisprudensi Islam}

Kedudukan Alquran dan Sunah merupakan sumber utama pengetahuan, sumber pokok hukum (mashadir al-ahkam), atau sebagai sumber dasar metodologi yurisprudensi hukum Islam. Alquran telah sempurna diturunkan dan Hadis telah berakhir terbit dengan wafatnya Rasulullah saw. Berbagai aktifitas dalam Islam tidak boleh sampai bertentangan dengan kaidah-kaidah yang termaktub dalam sumber dimaksud.

Firman Allah dalam Alquran secara praksis seyogianya digeneralisasikan kepada prinsipprinsip moral dalam berbagai aktifitas dengan cara mengaitkan ungkapan-ungkapan spesifik Alquran beserta latar belakang dinamika sosiokultural dan dengan mempertimbangkan ratio-legis ('illat hukum) yang dinyatakan dalam ungkapan-ungkapan Alquran. ${ }^{5}$ Hakekat Alquran sebagai "firman Allah" (kalam Tuhan) bersandarkan pada aspek keyakinan dan karenanya menjadi dasar keimanan seseorang dan sumber acuan dalam melakukan berbagai aktifitas dalam kehidupan. ${ }^{6}$

Alquran sumber pertama yurisprudensi Islam. Legislasi Alquran pada dasarnya merupakan pernyataan-pernyataan Alquran yang bermuatan hukum, namun sekaligus juga merupakan kitabkitab prinsip dan seruan-seruan moral dalam berbagai aktifitas dan bukan dimaksudkan sekadar legislasi semata. ${ }^{7}$ Sebagai kebijakan-kebijakan moral Alquran mengangkat kedudukan "masyarakat kelas dua": wanita, anak-anak yatim, fakir-miskin, dan budak menuju terwujudnya kondisi keadilan sosial dan

5 Ditansliterasi dari gagasan Fazlur Rahman, Islam and Modernity: Transformation of an Intellectual Tradition, (Chicago: Chicago University Press, 1980), h. 6.

6 Efrinaldi, Reaktualisasi Hukum Islam, Suatu Kajian Metodologis dalam Pemikiran Fazlur Rahman, dalam Mimbar Hukum, No. 50 Thn. XII 2001, (Jakarta: Al-Hikmah \& DITBINBAPERA Islam Depag RI), h. 98.

${ }^{7}$ Pencapaian maksud dari legislasi Alquran tersebut akan semakin jelas terlihat jika dipandang dari konteks dan dari latar belakang sosiologis masyarakat Arab ketika masa turun wahyu, yang mana kehidupan manusia ketika itu diwarnai kesenjangan pola hubungan dan eksploitasi kelompok "masyarakat kelas satu” terhadap kelompok masyarakat kelas dua. Lihat: Efrinaldi, Reaktualisasi Hukum..., h. 99. 
persamaan esensial derajat manusia (asas musawah). ${ }^{8}$

Mengacu pada legislasi Alquran terkandung prinsip umum dan legal spesifik. Prinsip umum merupakan makna dan argumentasi di balik ketentuan legal-spesifik, terkadang dinyatakan secara eksplisit mengiringi ungkapan-ungkapan legal spesifik. Legislasi zakat dalam hal ini bertujuan untuk menciptakan keadilan sosial bidang ekonomi. Prinsip-prinsip umum ini secara praksis dijabarkan ke dalam aturan legal spesifik. Formula legal spesifik dimaksudkan sebagai solusi alternatif yang sarat dengan muatan nilai-nilai ilahiyyah transendental terhadap berbagai permasalahan aktual yang makin kompleks. Dengan demikian, ordonansi ilahiyyah tersebut mengandung aturan hukum spesifik dan sumber nilai serta muatan moral.

Menelaah ayat-ayat Alquran tampak ada yang bersifat prinsipil-definitif (qathi) dan kandungan general (zhanni). Ayat-ayat yang qathi mengandung makna yang cukup jelas dan spesifik, tidak memerlukan kepada interpretasi lain dari makna zhahir. Sedangkan ayat-ayat yang bersifat zhanni memerlukan interpretasi untuk bisa memahami kandungan maknanya. Porsi rasio sangat menentukan dalam melakukan interpretasi dalam konteks ini. Rumusan interpretasi yuristik yang bersifat rasional yang termuat dalam fikih menjadi mainstream dalam melakukan pengamalanpengamalan melalui penggunaan instrumeninstrumen tertentu secara mendasar.

Dengan menelusuri makna kandungan Alquran yang bersifat qathi dan zhanni itu, versi Hasbi, memberi petunjuk syariat ditetapkan bukan untuk membebani pelaksana hukum (mukallaf), tetapi guna memberi kemaslahatan bagi manusia. Tujuannya adalah untuk memelihara agama, jiwa, akal, keturunan dan kehidupan sejahtera bagi umat manusia secara universal. Sifat general dari ayat-ayat Alquran mengandung makna bahwa Alquran membiarkan masalah-masalah mu'amalah, siyasah, dan qadha (peradilan) berkembang menurut kebutuhan masa, keadaan dan tempat. Ini menjadi indikator bagi kedinamisan dan fleksibelitas nilai-nilai

\footnotetext{
${ }^{8}$ Fazlur Rahman, Mayor Themes of the Qur'an, (MinneapolisChicago: Biblioteca Islamica, 1980), h. 68.
}

Alquran, sebagai pedoman hidup manusia. ${ }^{9}$

Dewasa ini problematika manusia banyak termasuk dalam kategorisasi mu'amalah. Spektrum muamalah didominasi oleh ayat-ayat yang bersifat zhanni dibanding qathi. Karena itu, paradigma ijtihadiyah yang didasarkan pada epistemologi Islam sangat fleksibel sesuai dengan dinamika dan mobilitas perubahan sosiokultural. Pengembangan kajian-kajian sebagai upaya reformasi hukum dalam Islam sudah seyogianya mengacu pada analisis faktual terhadap implementasi konsep-konsep dalam dinamika perubahan sosial yang terjadi.

Penafsiran terhadap Alquran yang faktual seyogianya dilakukan. Resiko terbesar dalam upaya seperti ini, tentu saja adalah timbulnya proyeksi ide-ide subyektif ke dalam Alquran dan menjadikannya sebagai objek perlakuan arbiter, namun konsekuensi ini dapat diminimalisir, maka suatu metodologi yang seksama untuk memahami dan menafsirkan Alquran harus digunakan dan diterapkan.

Sewaktu menafsirkan Alquran, pertama kali tentu dicari penjelasannya pada Alquran sendiri. Sebab, seringkali ada ayat-ayat yang disebutkan secara ringkas pada suatu tempat, sedangkan penjelasannya mencuat pada ayat lain. Jika tidak ditemukan ayat yang menjadi penjelas bagi sesuatu yang hendak ditafsirkan, kemudian dicari penjelasannya pada hadis. Sebab, Rasul lebih mengetahui makna hakiki suatu perintah atau berita yang disampaikan kepadanya. Jika dalam hadis tidak ada penjelasan, dilihat pada penafsiran sahabat. Penafsiran ini lebih dekat kepada kebenaran, karena para sahabat secara langsung mendengar sendiri dari Rasul dan menyaksikan sebab-sebab turun (asbab alnuzul) ayat. Apalagi para sahabat mengetahui benar tentang bahasa Arab, lebih khusus lagi, bahasa Arab yang dipakai ketika ayat-ayat itu diturunkan pada waktu itu.

Menelaah pemahaman terhadap arti atau makna suatu pernyataan (ayat) sangat penting,

9 TM. Hasbi Ash-Shiddieqy, Syariat Islam Menjawab Tantangan Zaman, (Jakarta: Bulan Bintang, 1966), h.7-10, dan Dinamika dan Elastisitas Hukum Islam, (Jakarta: Tinta-mas, 1976), h. 24-26. 
termasuk dengan mengkaji situasi atau problema historis di mana pernyataan Alquran tersebut merupakan jawabannya. Tentu saja sebelum mengkaji ayat-ayat spesifik dalam situasi-situasi spesifiknya, suatu kajian mengenai situasi makro dalam batasan-batasan masyarakat, agama, adatistiadat, lembaga, bahkan keseluruhan kehidupan masyarakat, terutama masyarakat di Arabia pada saat Islam datang dan khususnya Makkah dan sekitarnya, serta konteks keindonesiaan, harus dilakukan terlebih dahulu.

Pada tahap berikutnya, menggeneralisasikan respon-respon spesifik tersebut dan menyatakannya sebagai ungkapan-ungkapan yang memiliki tujuan moral-sosial umum, yang dapat "disaring" dari ungkapan-ungkapan ayat spesifik dalam sinaran latar belakang sosio-historis dan dalam sinaran rationes legis (illat) hukum yang sering dinyatakan. Alquran merupakan suatu kesatuan, sehingga setiap arti dari ayat tertentu yang dipahami, setiap hukum yang dinyatakan, dan setiap tujuan yang dirumuskan akan koherensi dengan lainnya. Alquran sendiri mendakwakan secara pasti bahwa "ajarannya tidak mengandung kontradiksi, melainkan koheren secara keseluruhan”.

Makna pokok terkandung dalam ayat-ayat spesifik menuju kepada prinsip, atau dengan kata lain, berfikir dari aturan-aturan legal spesifik menuju kepada muatan moral sosial yang bersifat umum yang terkandung di dalamnya. Ada tiga perangkat untuk dapat menyimpulkan prinsipprinsip moral sosial. Pertama, perangkat illat al-hukm (ratio legis) yang dinyatakan dalam Alquran secara eksplisit. Kedua, illat al-hukm yang dinyatakan secara implisit yang dapat diketahui dengan cara menggeneralisasikan beberapa ungkapan spesifik yang terkait. Ketiga, perangkat sosio-historis yang bisa berfungsi untuk menguatkan illat al-hukm secara implisit untuk menetapkan arah maksud tujuannya, juga dapat berfungsi untuk membantu mengungkapkan illat al-hukm beserta tujuannya yang sama sekali tidak dinyatakan secara eksplisit. ${ }^{10}$

Setelah Alquran, sumber kedua yurisprudensi

${ }^{10}$ Fazlur Rahman, Toward Reformulating the Methodology of Islamic Law, dalam "International Law and Politics", (vol. 12, 1972), h. 221-222.
Islam adalah Sunah. Secara leksikal, sunah mengandung arti shawwara (mencipta) dan al-sirah (perilaku kehidupan). Selain itu, Sunah juga bisa berarti cara atau kebiasaan hidup (custom or habitual actions). Dengan demikian, sunah dimaksudkan sebagai "tingkah laku yang merupakan teladan (exemplery counduct) baik berupa filiyah (doing. perbuatan), qauliyah (saying: ucapan), maupun sukutiyah (unconducting. diam).

Dengan demikian, kurang tepatjika term sunah diartikan dalam konteks fi'liyah saja. Menurut Fazlur Rahman (intelektual Islam asal Pakistan), kepatuhan terhadap sunah (sifat normatif) dalam tesa historis tidak merupakan bagian integral dari sunah, melainkan berasal dari otoritas di luar sunah, walaupun untuk menyempurnakannya, sunah tersebut perlu dipatuhi ${ }^{11}$. Dalam konteks ini, sunah tidak diartikan sebagai "praktek normatif," karena sunah yang berkembang pada masyarakat awal muslim bukanlah sunah Nabi melainkan kebiasaan orang Arab pra Islam yang dimodifikasi Alquran. Dengan demikian, hadis dengan sunah memiliki "diferensiasi” yang khas. Hadis secara orisinil berasal dari Nabi, bukan berasal dari sunah (praktek) yang hidup saat itu dan bersifat normatif. ${ }^{12}$ Meskipun menurut para ahli hadis, sunah sama dengan hadis, tetapi pada hakekatnya ada perbedaan. Hadis ialah semua peristiwa yang disandarkan kepada Nabi, walaupun hanya sekali saja terjadi di sepanjang hayatnya, sedangkan sunah adalah amaliah Nabi yang mutawatir, lebih khusus dari segi maknanya.

Dalam perkembangannya, sunah mengalami evolusi historis menjadi sunah yang hidup dan selanjutnya diformalisir menjadi hadis. Dalam perspektif mayoritas ahli usul fikih, konsep sunah atau hadis berkembang cukup bervariasi: hadis mutawatir, masyhur, ahad, maudhu', dan lainlain, dengan berbagai peringkat kehujjahannya: shahih, hasan, dha'if, dan lain-lain.

Dari segi lafal penukilannya, meskipun sunah tidak mutawatir yang menyebabkan sanadnya pun menjadi tidak mutawatir, namun karena pelaksanaannya mutawatir, maka tetap dinamakan

\footnotetext{
${ }^{11}$ Fazlur Rahman, Islamic Methodology in History, (Karachi: Institute of Islamic Research, 1965), h. 12.

${ }^{12}$ Fazlur Rahman, Islam and Modernity..., h. 46.
} 
sunah. Suatu kewajiban bagi umat Islam untuk mengamalkan hadis dan Sunah. Apalagi hadis shahih dan tidak berlawanan dengan petunjuk Alquran, wajib menjadi pedoman bagi umat Islam di setiap situasi dan kondisi yang terjadi. ${ }^{13}$

Berkenaan tentang kualifikasi hadis, hadis shahih adalah hadis yang tidak mengandung cacat pada susunan matannya, tidak bertentangan dengan Alquran atau khabar mutawatir dan jalur sanadnya terdiri dari orang-orang yang adil dan kuat hafalannya. Sedangkan hadis Ahad, berbeda dengan mutawatir atau tidak sampai pada tingkat mutawatir, karena perawinya sedikit. Kedudukan hadis Ahad ini adalah dzhanni. Hadis Ahad tidak dapat menghapuskan hukum yang telah ditetapkan Alquran, sebagaimana dinukilkan dalam pendapat al-Syafi'i. Ada pendapat lain bahwa hadis Ahad juga tidak bisa dipakai sebagai takhshish bagi pengertian umum yan tersebut dalam Alquran, kecuali kandungan hadis itu telah di-ijmåi ulama.

Mengkaji tentang hadis dhäif, tampak bahwa hadis dha'if tidak dapat digunakan dalam menetapkan suatu hukum, sebagaimana ditandaskan oleh mayoritas ulama. Perbedaan pendapat berkisar dalam penggunaan hadis dha'if sebagai penjelas untuk keutamaan amal (fadhail al-amal). Penggunaan hadis dha'if untuk menetapkan suatu perbuatan berhukum sunat, juga tidak dapat dibenarkan.

Kedudukan sunah selain sebagai bayan terhadap Alquran juga sebagai tasyri' (legislasi Islam) ${ }^{14}$ dalam berbagai persoalan. Otoritas bayan sunah Nabi antara lain dalam bentuk tafsir al-mubham, tafshil al-mujmal, taqyid almuthlaq, takhshish al-'am. ${ }^{15}$ Semua bentuk bayan ini merupakan otoritas sunah sebagai tasyri, yakni sebagai penetap hukum yang bersifat independen, dalam kasus-kasus yang Alquran tidak menetapkan hukumnya, ${ }^{16}$ merupakan

${ }_{13}$ TM. Hasbi Ash-Shiddieqy, Sejarah dan Pengantar Ilmu Hadis, cetakan keempat, (Jakarta: Bulan Bintang, 1974), h.2225, 39-40.

14 Konsep Otoritas Sunnah dalam kajian usul fikih dirumuskan dalam konteks istinbath al-ahkam.

15 Muhammad 'Ajjaj al-Khathib, Al-Sunnah Qabla alTadwin, (Mesir: Maktabah Wahbah, 1963), h. 23-26.

16 'Ajjaj al-Khathib mengungkap contoh pada Sunnah Nabi otoritas Nabi yang bersifat ekstra Qur'aniy. ${ }^{17}$

Kedudukan dan fungsi atau sifat otoritas sunah Nabi lebih cenderung sebagai konsep perilaku, yang jika dipandang dari sisi Alquran, sunah merupakan upaya operasional, karena itu lebih mencerminkan muatan situasional pada zamannya, kecuali yang menyangkut aspek religiusitas dan moral Islam. ${ }^{18}$

Karakteristik dan sifat otoritas sunah Nabi, seiring dengan ungkapan-ungkapan legal spesifik Alquran, seyogianya pemikiran- pemikiran seputar ini makin dikembangkan agar situasi dan kondisi baru dapat tercakup ke dalamnya. Dalam konteks ketetapan legal spesifik Alquran, kedudukan Sunah Nabi merupakan model atau pola aplikasinya. Sedang ketetapan legal spesifik Alquran merupakan penjabaran dari prinsipprinsip umum Alquran. Perlu ada nuansa baru dalam reinterpretasi terhadap Alquran dan sunah sehingga lebih adaptatif dengan dinamika perubahan sosial yang mengitari umat Islam.

\section{Signifikasi ljtihad dalam Kajian IImu Usul Fikih}

Dalam perspektif ilmu usul fikih, ijtihad merupakan suatu metode dalam penggalian makna dan materi hukum dengan kemaslahatan sebagai tujuannya. Dalam konteks sekarang, ijtihad dapat berarti sebagai kerja progresif untuk memperbarui aturan-aturan yang terkandung dalam teks Alquran atau sunah agar keduanya mampu mencakupi situasi dan kondisi baru dengan memberikan suatu solusi (aturan hukum) terhadap berbagai problematika yang terjadi. ${ }^{19}$

Bagi kalangan al-ushuliyyun (para ahli usul fikih) adalah suatu keniscayaan untuk menggali hukum terhadap peristiwa-peristiwa hukum dalam berbagai bidang, terutama yang me-

yang melarang jual-beli buah-buahan yang masih muda dan belum tampak. Lihat: 'Ajjaj al-Khathib, Al-Sunnah Qabla..., h. 26.

${ }^{17}$ Efrinaldi, Reaktualisasi Hukum..., h. 101.

${ }^{18}$ Sebagai ilustrasi teoretis dari hal ini, misalnya ketetapan sunah Nabi atas objek harta wajib zakat, atau Sunnah Nabi ketika harus mengambil keputusan meringkas dan menjamak (qashar dan jama') salat dalam suatu jarak safar (perjalanan), berkaitan erat dengan setting sosial masyarakat Arab pada masa itu. Telaah dalam: Fazlur Rahman, Islamic Methodology..., h. 51.

19 Fazlur Rahman, Islam and Modernity, Transformation of Intellectual Traditions, (Chicago: Chicago University Press, 1982), h. 8. 
nyangkut porsi dalil dalil yang dzanni secara maksimalis, yang belum ada penetapan hukumnya berdasar nash. Fuqaha' kontemporer seyogianya mereformulasi konsepsi fikih yang up to date yang akomodatif dengan perkembangan situasi dan kondisi dalam kehidupan masyarakat modern. Problematika hidup masyarakat memang makin beragam. Terhadap masalah yang berkenaan dengan hukum yang belum ada penetapan hukumnya, tidak ada jalan lain kecuali berijtihad. Ijtihad merupakan suatu tugas mulia para ahli hukum Islam kontemporer sebagai upaya memberikan solusi alternatif dari berbagai masalah hukum yang makin kompleks tersebut.

Pembaruan hukum Islam tidak dapat dilakukan, jika sikap skeptis dan jumud masih melanda para ulama dan umat Islam. Sebaliknya, sikap progresif dan dinamis amat penting, tetapi sikap hati-hati tetap merupakan suatu keharusan. Oleh sebab itu, dalam penyelesaian problematika yang berkenaan dengan hukum, tidak semua orang mempunyai kapabilitas. Orang yang boleh berijtihad mempunyai syarat-syarat tertentu, seperti berkepribadian kokoh dan jujur, mempunyai otoritas yurisprudensi, sangat probabilitas untuk ber-istinbath dan ber-istidlal dalam merepresentasi makna substantif syara' secara mendalam.

Penerapan dan proses dalam berijtihad, teks Alquran dan preseden (Sunah) dapat dipahami untuk digeneralisasikan sebagai prinsipprinsip dan bahwa prinsip-prinsip tersebut lalu dapat dirumuskan menjadi aturan-aturan yang baru. Dalam mekanisme kerja ijtihad meliputi pemahaman teks dan preseden dalam keutuhan konteksnya di masa lampau, pemahaman situasi baru yang sedang terjadi sekarang, dan pengubahan aturan-aturan hukum yang terkandung di dalam teks atau preseden. Reformulasi konsepsi ijtihad ini difungsikan sebagai upaya pembaruan hukum Islam, demikian juga sebagai upaya menjawab tantangan situasi baru dalam konteks keindonesiaan.

Dalam hal ini ijtihad adalah satu-satunya cara untuk mengantisipasi perubahan dan hukum Islam dapat akomodatif dengan perkembangan masyarakat. Meskipun demikian, ijma', qiyas, istihsan, 'urf, dan istis'hab tetap ditempatkan dalam posisi yang berbeda. Di satu pihak, dalil hukum ini bersama Alquran dan hadis sebagai sumber ijtihad, yang karenanya juga merupakan sumber hukum (mashadir al-ahkam). Namun pada sisi lain dalil hukum tersebut sebagai metode ijtihad (thuruq al-istinbath al-masalik).

Problematika yang semakin kompleks, sedangkan solusinya belum dirumuskan oleh para fukaha terdahulu, lalu mengacu pada ijtihad bi al-rajyi, yakni menentukan hukum berdasarkan pada maslahat, kaidah-kaidah kuliah, dan 'illat hukum. Pada tataran implementatif, metode tersebut meliputi: qiyas, istihsan, istishlah, urf, dan istishab. Metode-metode ini diaplikasikan selaras dengan kaidah-kaidah fikih yang relevan. Pengambilan keputusan hukum secara materia dan forma diambil melalui ijtihad jamäi (ijtihad kolektif) atau ijma' (konsensus). Dalam konteks legislasi, dengan acuan pada Alquran, sunah, atau rajyu, ditempuh melalui konsultasi atas perintah kepala negara, bukan ijtihad fardi. Kristalisasi hasil ijtihad menjadi ijma' tersebut dan kemudian kebijakan taqnin (penetapan hukum Islam menjadi undangundang) merupakan upaya sosialisasi hasil ijtihad dimaksud.

Metode dalam ijtihad yang ditempuh secara kolektif ini, atau lebih dikenal dengan sebutan ijtihad jamäi, karena dalam ijtihad ini akan menawarkan lebih banyak pilihan atau alternatif yang bersifat kualitatif. Sedangkan kalau semata diandalkan ijtihad fardi akan melahirkan banyak silang pendapat. Secara rasional, pandangan kolektif tentu akan lebih baik daripada pandangan yang bersifat personal dan terbatas.

Dalam upaya membumikan ijtihad kolektif, dengan menilik dinamika historisitas Islam betapa signifikannya pendirian lembaga abl al-hall walaqd. Lembaga ini ditopang oleh dua sub lembaga. Pertama, haiah siyasah (lembaga politik). Anggotaanggota lembaga ini terdiri dari orang-orang yang dipilih oleh rakyat, dari rakyat, dan untuk rakyat. Kategori kapabilitas dalam konteks ini, mereka tidak mesti memenuhi persyaratan mujtahid, tetapi cukup menguasai bidang yang diwakilinya. Kedua, haiah tasyriiyah (lembaga legislatif). Lembaga ini mencakup komponen ahl al-ijtihad dan ahl alikhtishas secara integral. 


\section{Karakteristik Substantif dalam Dinamika Pemikiran Hukum Islam}

Karakteristik pemikiran mengenai hukum Islam mencuat pada gagasan yang orisinil dalam dinamika dan kontekstualisasi hukum Islam. Dalam pandangan Hasbi Ash-Shiddieqy (19041975), prinsip al-mashlahah al-mursalah yang berasaskan keadilan dan kemanfaatan serta sadd $a d z$-dzariah (mencegah kerusakan) merupakan grand theory dalam kontekstualisasi pemikiran hukum Islam. Prinsip ini merupakan kombinasi dari prinsip-prinsip yang dipegang para imam mazhab, terutama aliran Madinah dan Kufah, yang terbukti mampu membawa ketertiban dan kesejahteraan dalam masyarakat. ${ }^{20}$

Secara etimologis, maslahat (al-mashlahah) diartikan sebagai sesuatu yang baik atau sesuatu yang bermanfaat. Secara leksikal, menuntut ilmu itu mengandung suatu kemaslahatan, maka hal ini berarti menuntut ilmu itu merupakan penyebab diperolehnya manfaat secara lahir dan batin. ${ }^{21}$

Al-Ghazali memformulasikan teori kemaslahatan dalam kerangka "mengambil manfaat dan menolak kemudaratan untuk memelihara tujuantujuan syara." ${ }^{22}$ Suatu kemaslahatan, menurut al-Ghazali, harus seiring dengan tujuan syara', meskipun bertentangan dengan tujuan-tujuan manusia. Atas dasar ini, yang menjadi tolok ukur dari maslahat itu adalah tujuan dan kehendak syara', bukan didasarkan pada kehendak hawa nafsu manusia.

Tujuan syara' dalam menetapkan hukum itu pada prinsipnya mengacu pada aspek perwujudan kemaslahatan dalam kehidupan manusia. Muatan maslahat itu mencakup kemaslahatan hidup di dunia maupun kemaslahatan hidup di akhirat. Atas dasar ini, kemaslahatan bukan hanya didasarkan pada pertimbangan akal dalam memberikan penilaian terhadap sesuatu itu baik atau buruk, tetapi lebih jauh dari itu ialah sesuatu yang baik

20 TM. Hasbi Ash-Shiddieqy, Memoedahkan Pengertian Islam, dalam PandjiIslam, No. 39-40 (7 Oktober 1970), h. 790.

${ }^{21}$ Husain Hamid Hasan, Nazhariyah al-Mashlahah fi al-Fiqh al-Islamy, (Kairo: Dar al-Nahdhah al-Arabiyah, 1971), h. 3-4.

22 Abu Hamid al-Ghazali, Al-Mustashfa fi Ilm al-Ushul. (Beirut: Dar al-Kutub al-Ilmiyah, 1983), Jilid I, h. 286. secara rasional juga harus sesuai dengan tujuan syara'.

Mengacu kepada kepentingan dan kualitas kemaslahatan itu, pada prinsipnya penetapanpenetapan hukum (tasyri) dimaksudkan untuk mewujudkan kemaslahatan itu secara substantifuniversal dengan mengklasifikasikan teori almashlahah kepada tiga jenis, sebagaimana juga dirumuskan secara general oleh para teoritisi hukum Islam. ${ }^{23}$ Pertama, mashlahah dharuriyah, yaitu kemaslahatan yang sangat dibutuhkan dalam kehidupan manusia di dunia dan di akhirat. Kemaslahatan ini berkaitan dengan lima kebutuhan pokok, yang disebut dengan al-mashalih al-khamsah, yaitu (1) memelihara agama, (2) memelihara jiwa, (3) memelihara akal, (4) memelihara keturunan, dan (5) memelihara harta.

Segala sesutu yang tidak sesuai dengan kelima unsur pokok di atas adalah bertentangan dengan tujuan syara'. Karena itu, tindakan tersebut dilarang tegas dalam agama. Allah melarang murtad demi untuk memelihara agama; membunuh dilarang untuk memelihara jiwa, minum-minuman keras dilarang untuk memelihara akal sehat, berzina diharamkan untuk memelihara keturunan, dan mencuri atau merampok dilarang untuk memelihara kepemilikan terhadap harta.

Kedua, mashlahah hajiyah, yaitu kemaslahatan yang keberadaannya dibutuhkan dalam menyempurnakan lima kemaslahatan pokok tersebut yang berupa keringanan demi untuk mempertahankan dan memelihara kebutuhan dasar (basic need) manusia. Misalnya, rukhshah berupa kebolehan berbuka puasa bagi orang yang sedang musafir, kebutuhan terhadap makan untuk mempertahankan kelangsungan hidup, menuntut ilmu untuk mengasah otak dan akal, berniaga untuk mendapatkan harta. Semua ini disyariatkan untuk mendukung pelaksanaan kebutuhan lima pokok tersebut.

${ }^{23}$ Abu Ishaq al-Syathibi, Al-Muwafaqat fi Ushul al-Syariah, (Beirut: Dar al-Ma’rifah, 1973), jilid II, h. 8-12, Ibn al-Hajib, Mukhtashar al-Muntaha', (Mesir: Al-Mathba'ah al-Amiriyah, 1328 H), Jilid II, h. 240 dan Abu Hamid al-Ghazali, AlMustashfa fi Ilm..., h. 139. 
Ketiga, mashlahah tahsiniyyah, yaitu kemaslahatan yang bersifat pelengkap (komplementer) berupa keleluasaan yang dapat memberikan nilai plus bagi kemaslahatan sebelumnya. Kebutuhan dalam konteks ini perlu dipenuhi dalam rangka memberi kesempurnaan dan keindahan bagi hidup manusia. Umpamanya, dianjurkan memakan yang bergizi, berpakaian yang rapi, melaksanakan ibadahibadah sunah, dan lain sebagainya.

Ditinjau dari dimensi cakupan kemaslahatan, para ahli mengklasifikasikan teori ini kepada dua hal. Pertama, mashlahah 'ammah, yaitu kemaslahatan umum yang berhubungan dengan kepentingan masyarakat banyak atau mayoritas umat. Misalnya, ulama membolehkan membunuh penyebar bid'ah dan dhalalah karena dapat merusak aqidah mayoritas umat.

Kedua, mashlahah khasshah, yaitu kemaslahatan khusus yang berhubungan dengan kemalahatan individual. Misalnya, kemaslahatan yang berkenaan dengan pemutusan hubungan status perkawinan terhadap seseorang yang dinyatakan hilang (mafqud).

Urgensi dari pengklasifikasian kedua jenis kemaslahatan ini berkaitan dengan skala prioritas manakala antara teori kemaslahatan umum dengan kemaslahatan individual terjadi perbenturan. Dalam konteks ini, mendahulukan kemaslahatan umum dari kemaslahatan pribadi menjadi suatu keniscayaan.

Dalam aspek keberadaan mashlahah dalam perspektif syara' dan adanya keselarasan antara anggapan baik secara rasional dengan tujuan syara', teori ini diklasifikasikan kepada tiga hal. ${ }^{24}$ Pertama, mashlahah mu'tabarah, yaitu kemaslahatan yang berada dalam kalkulasi syara'. Dalam hal ini, ada dalil yang secara khusus menjadi dasar dari bentuk kemaslahatan itu, baik secara langsung ada indikator dalam syara' (munasib mu'atstsir) ataupun secara tidak langsung ada indikatornya (munasib mulaim).

Misalnya salah satu bentuk hukuman bagi pencuri adalah keharusan mengembalikan barang curian kepada pemiliknya, apabila masih utuh atau mengganti dengan sesuatu yang sama

\footnotetext{
${ }^{24}$ Abu Ishaq al-Syathibi, Al-Muwafaqat fi Ushul..., h. 12.
}

nilainya. Hukuman ini dianalogikan kepada ketentuan hukuman ghashab (orang yang mengambil harta orang lain tanpa izin), sebagai suatu syarat mengambil barang orang lain tanpa izin pemiliknya.

Kedua, mashlahah mulghah, yaitu bentuk kemaslahatan yang ditolak, karena bertentangan dengan ketentuan syara'. Meskipun sesuatu itu secara rasio dianggap baik, tetapi syara' menetapkan hukum yang berbeda karena muatan maslahat itu. Misalnya, dewasa ini dengan alasan gender dan emansipasi wanita, secara rasional dapat diterima kedudukan yang sama antara hak perempuan dan laki-laki dalam memperoleh harta warisan. Tetapi berdasarkan ketentuan syara', hak waris anak laki-laki tetap dua kali lipat hak anak perempuan (QS. Al-Nisa' (4): 11 dan 176).

Ketiga, mashlahah mursalah, atau dalam beberapa literartur disebut juga dengan al-istishlah, mashlahah muthlaqah, atau munasib mursal. Yaitu kemaslahatan yang eksistensinya tidak didukung syara' dan esensinya tidak pula ditolak melalui dalil yang terperinci, tetapi cakupan makna nash terkandung dalam substansinya. Dalam hal ini, sesuatu itu dalam anggapan baik secara rasio dengan pertimbangan untuk mewujudkan kemaslahatan bagi manusia. Sesuatu yang baik menurut rasio akan selaras dengan tujuan syara' dalam penetapan hukum, yang secara khusus tidak ada indikator dari syara' untuk menolak ataupun mengakui keberadaannya.

Mashahah mursalah dalam kedudukan sebagai metode ijtihad secara jelas juga digunakan oleh Imam Malik beserta penganut mazhab Maliki. Selain itu, mashlahah mursalah juga digunakan kalangan ulama non-Maliki sebagaimana dinukilkan pula oleh al-Syathibi.

Atas dasar kemaslahatan itu, dalam fikih dikenal adanya siyasah syar'iyah, yakni suatu metode kebijaksanaan agar masyarakat lebih kondusif dan interest terhadap kebajikan dan menjauhi keburukan dan kerusakan. Substansi mashlahah mursalah ini yang digali melalui qiyas, kaidah umum (qawaid 'ammah) hukum dan istihsan. Memang, hukum yang dinashkan syara' yang didasarkan atas 'illat, bertujuan untuk mewujudkan kemaslahatan bagi manusia, 
demikian versi Jumhur ulama. ${ }^{25}$

Menilik kepada pendapat Hasbi AshShiddieqy, jika menggunakan qiyas semata dalam memecahkan masalah hukum, seperti konsep al-Syafi'i, akan menimbulkan kesulitan dan kesempitan. Karena, qiyas kadangkala tidak dapat memenuhi tuntutan perubahan kebutuhan masyarakat, sedangkan mashlahah mengalami perubahan secara kontinuitas. ${ }^{26}$

Dalam konteks itu, konsep qiyas Malik yang berlandaskan mashlahah mursalah dan konsep rayu Abu Hanifah yang berlandaskan istihsan, selain mengandung makna yang sama, keduanya juga mengarah kepada terwujudnya satu tertib hukum yang mengayomi dan memberi kemaslahatan bagi masyarakat. Atas dasar ini, penggunaan prinsip mashlahah mursalah sebenarnya juga penggunaan qiyas. Differensiasinya, jika qiyas dikaitkan dengan nash tertentu, sedangkan mashlahah mursalah dihubungkan dengan jiwa syariat.

Kemaslahatan umum dalam perspektif hukum Islam adalah sesuatu yang prinsip. Prinsip maslahat sebagai dasar orientasi perkembangan hukum Islam telah disepakati oleh para teoritisi hukum Islam. Grand theory ini kemudian dikombinasikan dengan sadd al-dzariah. Sebagai prinsip hukum, sadd al-dzariah secara substantif digunakan oleh para ahli hukum Islam. Dengan mengacu pada prinsip sadd al-dzariah ini, pemerintah dibenarkan melakukan pengawasan atas nilai sewa, pemilikan tanah, penggunaan harta kekayaan dan sebagainya. ${ }^{27}$

Dasar pemikiran dengan berpegang pada dua prinsip ini, yakni al-mashlahah al-mursalah dan sadd al-dzariah adalah karena kemaslahatan umum, keadilan dan kemanfaatan serta mencegah timbulnya kerusakan merupakan suatu hal yang rasional dan menjadi kebutuhan bagi ketenteraman dan kesejahteraan hidup manusia. Inilah tujuan yang paling signifikan dari penetapan hukum Islam.

Tujuan syara' secara substansial memang untuk

${ }_{25}$ TM. Hasbi Ash-Shiddieqy, Dinamika dan Elastisitas Hukum Islam, (Jakarta: Tinta-Mas, 1976), h. 33-35.

26 TM. Hasbi Ash-Shiddieqy, Falsafah Hukum Islam, (Jakarta: Bulan Bintang, 1975), h.331-351.

${ }_{27}$ TM. Hasbi Ash-Shiddieqy, Falsafah Hukum..., h.324-326. terciptanya kemaslahatan umum (public interest) dalam kehidupan manusia tersebut. Kemaslahatan umum itu bersifat dinamis dan fleksibel yang seiring dengan lajunya perkembangan zaman. Nilai-nilai dan tujuan syara' dengan pertimbangan kemaslahatan umum dan mencegah kerusakan menjadi solusi alternatif terhadap kompleksitas permasalahan kehidupan manusia.

\section{Penutup}

Reformulasi pemikiran hukum Islam mesti selalu berpijak pada nash. Makna esensial dari pembaruan itu sendiri bukan berarti meninggalkan nash. Dalam hal ini, ditekankan bahwa pembaruan itu dengan memperbarui barang lama yang telah usang dengan mengembalikannya seperti keadaan semula. Pembaruan hukum dilakukan dengan mengembalikan pada muatan prinsip dan asas-asas hukum, bukan dengan merombak atau menghancurkan sendi-sendi hukum. Sumber hukum Islam adalah Alquran dan Sunah. Wacana pembaruan hukum ini selalu berlandaskan pada kedua sumber ini.

Pembaruan dilakukan dalam lapangan yang menjadi garapan ijtihad. Lapangan tersebut adalah masalah-masalah atau peristiwa-peristiwa yang memerlukan penetapan hukum yang prinsip-prinsip umumnya (mabadi 'ammah) telah ada dalam syariat dan prinsip-prinsip umum serta hukum-hukum yang terinci mengenai masalah atau perkara yang mubah.

Pembaruan hukum Islam malah tidak dapat dilakukan, jika sikap skeptis dan jumud masih melanda para ulama dan umat Islam. Sebaliknya, sikap progresif dan dinamis amat penting, tetapi sikap hati-hati tetap merupakan keharusan. Oleh sebab itu, dalam penyelesaian problematika yang berkenaan dengan hukum, tidak semua orang mempunyai kapabilitas. Orang yang boleh berijtihad mempunyai syaratsyarat tertentu, seperti berkepribadian kokoh dan jujur, mempunyai otoritas yurisprudensi, sangat probabilitas untuk ber-istinbath dan ber-istidlal dalam merepresentasi makna substantif syara', sebagaimana mencuat dalam ilmu usul fikih. 


\section{Pustaka Acuan}

Abidin, Ibn, Radd al-Mukhtar 'ala al-Durr alMukhtar, Jilid IV, Beirut: Dar al-Fikr, 1983.

Ash-Shiddieqy, T.M. Hasbi, Dinamika dan Elastisitas Hukum Islam, Jakarta: Tintamas, 1976.

Ash-Shiddieqy, T.M. Hasbi, Falsafah Hukum Islam, Jakarta: Bulan Bintang, 1974.

Ash-Shiddieqy, T.M. Hasbi, Figh Islam Mempunyai daya Elastis, Lengkap, Bulat, dan Tuntas, Jakarta: Bulan Bintang, 1975.

Ash-Shiddieqy, T.M. Hasbi, Pengantar Ilmu Fiqh, Jakarta: Bulan Bintang, 1989.

Audah, Abdul Qadir, Al-Amal al-Kamilah. Kairo: Al Mukhtar al-Islamy, 1994.

Begm, M.A.J., Social Mobility in Islamic Civilization, alih bahasa Adeng Mukhtar AlGhazali dan Thoriq A. Hinduan, Mobilitas Sosial dalam Peradaban Islam, Bandung: Sinar Baru Al-Gensindo, 1987.

Bello, Iysa A., The Medieval Islamic Controversy Between Philosophy and Orthodoxy, Ijma' and Tawil in the Conflict Between Al-Ghazali and Ibn Rusyd, New York: E.J Brill, 1989.

Coulson, Noel J., Conflicts and Tensions in Islamic Jurisprudence, Chicago: The University of Chicago Press, 1969.

Darini, Fath al-, al-Figh al-Islami al-Muqarin ma'a al-Madzahib, Damaskus: Mathba'ah Tarbin, 1979.

Efrinaldi, Reaktualisasi Hukum Islam, Suatu Kajian Metodologis dalam Pemikiran Fazlur Rahman, dalam Mimbar Hukum, Jakarta: AlHikmah \& DITBINBAPERA Islam Depag RI, No. 50 Thn. XII 2001.

Ghazali, Abu Hamid Muhammad ibn Muhammad al-, Al-Mustashfa Min Ilmi alUshul, Beirut : Dar el-Fikr, 1991.

Hakim, Abdul Hamid, Al-Bayan, PadangPanjang: Pustaka Sa'adiyah, t.th.

Hakim, Abdul Hamid, Al-Mu'in al-Mubin, juz 4, Jakarta: Bulan Bintang, 1976.

Hakim, Abdul Hamid, Mabaadi Awwaliyah, Jakarta: Sa'adiyah Putra, t.th.

Hammad, Nazih, Mujam al-Mushthalahat alIqtishadiyah fi Lughah al-Fuqaha'. Riyadh: al-Ma'had al'Alamy li al-Fikr al-Islamy, 1995.
Hummam, Ibn al-, Al-Kamal, Fath al-Qadir Syarh al-Hidayah, Beirut: Dar al-Fikr, 1980.

I. Doi, Abd. Al-Rahman, Shariah: The Islamic Law, Kuala Lumpur: AS Noordeen, 1984.

Jaziry, Abd al-Rahman al-, Kitab al-Figh ala alMadzahib al-Arba'ah, qism al-mu'amalah. Kairo: Istiqamah, 1970.

Khallaf, Abd al-Wahab, 'Ilm Ushul Al-Fiqh. Jakarta: Al-Nasyr al-Majlis al-A'la al-Indonesy I Dakwah la-Islamiyah, $1392 \mathrm{H}$.

Kompilasi Hukum Islam, Inpres No. 1 Th. 1991, Surabaya: Karya Anda, 1996.

Mahally, Jalaluddin al-, Qulyubi wa Amirah, Mesir: Musthafa al-Babie al-Halabi, t.th.

Mahjuddin, Masail al-Fiqhiyyah, Jakarta: Kalam Mulia, 1989.

Mughniyah, Muhammad Jawad al-, Al-Ahkam al-Syakhshiyah, Mesir: Dar al-Ilm li alMalayin, 1964.

Nourouzzaman Shiddiqi, Figh Indonesia, Penggagas dan Gagasannya, Yogyakarta: Pustaka Pelajar, 1997.

Nuruddin, Amir, Ijtihad Umar ibn Al- Khattab, Studi tentang Perubahan Hukum dalam Islam. Jakarta : Rajawali Pers, 1991.

R. Van Dijk Pengantar Hukum Adat di Indonesia, terj., Mr. A. Soekardi, Vorink van Koeve, Bandung: Graenhage, t.th.

Rahman, Fazlur, Islam and Modernity: Transformation of an Intellectual Tradition, Chicago: Chicago University Press, 1980.

Rahman, Fazlur, Islamic Methodology in History. Karachi: Institute of Islamic Research, 1965.

Rahman, Fazlur, Mayor Themes of the Qur'an. Minneapolis-Chicago: Biblioteca Islamica, 1980.

Salam, 'Izz al-Din Ibn Abd al-, Qawaid alAhkam fi Mashalih al-Anam, Beirut: Dar alKutub al-'Ilmiyah, t.th.

Syahawi, Ibrahim Al-Suqy al-, Kitab Al-Syahawi fi Tarikh al-Tasyri al-Islamy, Kairo: Syirkah AlThiba'ah al-Funniyah al-Mut hahidah, 1969.

Syathibi, Abu Ishaq al-, Al-Muwafaqat fi Ushul al-Syariah, Jilid II. Beirut: Dar al-Fikr, 1973.

Zuhaily, Wahbah al-, Ushul Al-Figh Al-Islamy, Libanon: Dar al-Fikr, 1989. 